Jurnal Psikologi Teori dan Terapan

2016, Vol. 6, No. 2, 91-101, ISSN: 2087-1708

\title{
Gambaran Kepribadian Hardiness Atlet Paralympic Atletik Lari Cepat
}

\author{
Gretty Wida Kinanthi, Miftakhul Jannah \\ Program Studi Psikologi Universitas Negeri Surabaya
}

\begin{abstract}
Abstrak: Penelitian ini dilatarbelakangi oleh fenomena atlet paralympic dengan ketidakmampuan secara fisik, penglihatan, pendengaran dan intelektual yang dituntut untuk tetap percaya diri dan mampu mengatasi permasalahan. Stres seringkali terjadi pada atlet ketika pertandingan berlangsung sehingga stres ini menyebabkan kegagalan dipertandingannya dan mereka dituntut untuk bangkit kembali setelah kegagalan. Atlet membutuhkan kecenderungan kepribadian hardiness untuk mengatasi setiap masalah dalam pertandingan sehingga atlet dapat mencapai prestasi. Tujuan penelitian ini adalah untuk menggambarkan kecenderungan kepribadian hardiness atlet paralympic. Penelitian ini menggunakan penelitian kualitatif dengan metode studi kasus. Atlet paralympic yang memiliki prestasi tingkat internasional nomor perlombaan lari cepat 200 dan 400 meter dipilih sebagai partisipan pada penelitian ini. Data dikumpulkan dengan wawancara, observasi dan dokumentasi. Hasil menunjukkan bahwa partisipan memiliki kecenderungan kepribadian hardiness yang ditunjukkan dengan pemahamannya pada tujuan hidup, melibatkan diri dalam aktivitas sehari-hari, pengendalian setiap masalah. Partisipan juga memiliki optimis dan berani mengambil tantangan.
\end{abstract}

Kata kunci: Kecenderungan kepribadian hardiness, stres, atlet paralympic.

\begin{abstract}
This research was motivated by a phenomenon of paralympic athletes with physical, visual, hearing and intellectual dissabilities that were demanded to keep confident and overcome problems. Stress often happens to athletes when the match is in progress so this stress causes failure on their competition and they are demanded to come up again after failure. Athletes need a tendency of hardiness personality to overcome every problem in the match so the atheletes can gain an achievement. The purpose of this research was to describe a paralympic athlete's tendency of hardiness personality. This research used qualitative research with case-study method. A paralympic athelete who had international achievement in 200 and 400-meter sprints was recruited as the participant in this research. Data were collected using interviews, observations and document reviews which then analyzed by using thematic analysis. The results showed that the participant had tendency of hardiness personality shown by his understanding of the purpose of life, involving his self in daily activities, and controlling each of his problem. The participant also had optimism and ready to take the challenge.
\end{abstract}

Keywords: Tendency of hardiness personality, stress, paralympic atheletes.

Korespondensi tentang artikel ini dapat dialamatkan pada Gretty Wida Kinanthi melalui email: grettykiinanthy@gmail.com. 
Olahraga merupakan suatu aktivitas penting dalam kehidupan manusia. Menurut Giriwijoyo (2005), olahraga adalah serangkaian gerak tubuh yang teratur dan terencana yang dilakukan orang secara sadar untuk meningkatkan kemampuan fungsionalnya dengan baik. Olahraga selain menjadi hiburan untuk masyarakat juga menjadi sebuah ajang untuk bisa berprestasi. Perwujudan prestasi di dunia olahraga didukung oleh adanya pertandingan-pertandingan olahraga yang bermunculan sebagai ajang untuk berprestasi. Salah satu cabang olahraga yang dilombakan yaitu atletik. Menurut Nurhasan, dkk (2005) atletik adalah aktivitas jasmani yang kompetitif atau dapat dilombakan, meliputi beberapa nomor perlombaan yang terpisah berdasarkan kemampuan gerak dasar manusia seperti berjalan, berlari, melompat dan melempar. Cabang olahraga atletik ini sendiri terdiri dari beberapa pertandingan yang dilombakan di olimpiade, kejuaraan dunia atau nasional, salah satunya adalah nomor perlombaan lari.

Pertandingan dalam olahraga tidak hanya diperuntukkan oleh atlet normal, namun atlet dengan keterbatasan fisik, mental maupun sensorial juga mampu untuk menoreh prestasi dengan pelatihan khusus dan intensif. Atlet paralympic adalah atlet yang mengalami cacat mobilitas dan visual, diamputasi atau mengalami kelumpuhan otak sehingga membutuhkan pelatihan khusus untuk dapat mengasah dan meningkatkan kemampuan olahraga. Menurut Goldberg (dalam Johnson dkk, 2004) selama beberapa tahun terakhir, telah terjadi peningkatan penekanan pada peran olahraga dan aktivitas fisik dalam meningkatkan kesehatan dan kualitas hidup individu dengan kecacatan dan penyakit kronis.

Indonesia memiliki sejumlah atlet paralympic yang mempunyai prestasi di kancah nasional maupun internasional. Ketua Umum National Paralympic
Commite (NPC) Indonesia, Semmy Marbun mengatakan pandangan yang rendah mengenai kaum difabel harus diubah, sebab kaum difabel tetap mampu berprestasi sehingga mengharumkan nama bangsa dan negara Indonesia. Paralimpiade yang diadakan di London pada tahun 2012 mengirimkan 4 atlet difabel Indonesia, salah satu kontingen Indonesia mampu untuk menyabet medali perunggu. Atletatlet ini mampu membuktikan bahwa walaupun atlet-atlet difabel memiliki keterbatasan tapi hal itu tidak akan menciutkan semangat untuk berprestasi. Surabaya merupakan salah satu kota pencetak atlet paralympic yang dapat berprestasi baik diajang regional, nasional maupun internasional. Salah satu atlet paralympic Surabaya di cabang olahraga atletik yang menunjukkan kemampuannya ditingkat internasional yaitu Amin, Amin tergabung dalam National Paralympic Committee (NPC) di Surabaya yang memiliki prestasi dari tahun 1990 hingga tahun 2014.

Prestasi yang diraih baik di lingkup nasional maupun internasional merupakan kebanggaan tersendiri bagi atlet. Ada 3 faktor yang mempengaruhi pencapaian prestasi yang optimal pada atlet yaitu faktor fisik, teknik dan psikologis. Faktor psikologis memiliki peranan penting pada pencapaian prestasi yang tinggi, sekitar $80 \%$ faktor keberhasilan ditentukan oleh faktor psikologis (Adisasmito, 2007). Kondisi psikis atlet yang menurun selama pertandingan berlangsung akan mengakibatkan stres atau kecemasan. Stres atau kecemasan dalam pertandingan yang berlebihan dapat menyebabkan terganggunya fungsi pribadi seseorang, hal ini disebabkan daya tahan setiap individu berbeda.

Andersen dan Williams (dalam Wadey, 2009) mengusulkan enam ciri-ciri kepribadian berdasarkan literatur tentang stres yaitu, hardiness, lokus kontrol, rasa koherensi, perasaan mencari, motivasi berprestasi dan sifat kecemasan dari 
persaingan. Salah satu ciri kepribadian untuk menghadapi stres yaitu kepribadian hardiness. Kreitner dan Kinicki (2005) mengatakan bahwa hardiness melibatkan kemampuan secara sudut pandang atau secara keperilakuan mengubah stressor yang negatif menjadi tantangan yang positif. Menurut Mehrparvar dan Mazaheri (2012) individu yang memiliki kepribadian hardiness tidak menilai peristiwa sebagai ancaman, tetapi sebagai hal yang positif dan terkendali.

Atlet paralympic dengan keterbatasan secara fisik, mental atau sensorial memiliki tuntutan untuk tetap percaya diri dan mampu untuk mengatasi permasalahan. Kegagalan dalam pertandingan yang disebabkan oleh kecemasan saat bertanding dapat berpengaruh pada pertandingan selanjutnya. Ketakutan akan kegagalan sebagai akibat dari kegagalan pertandingan sebelumnya menjadi pemicu stres bagi atlet. Kepribadian hardiness diperlukan untuk mengubah situasi yang dapat menjadi stressor dan berdampak negatif bagi atlet paralympic menjadi situasi yang menyenangkan dan menjadi tantangan yang positif. Cabang olahraga atletik nomor perlombaan lari cepat, tekanan yang dihasilkan lebih tinggi. Hal ini dikarenakan nomor perlombaan lari cepat merupakan perlombaan yang dilakukan secara individu, sehingga saat mengalami kecemasan bertanding individu tersebut akan mengatasi sendiri tanpa adanya bantuan dari rekan tanding. Daya konsentrasi yang tinggi pada saat start juga diperlukan agar tidak melakukan kesalahan diawal saat pertandingan berlangsung. Atlet paralympic yang bertanding di nomor perlombaan lari cepat yang memiliki kepribadian hardiness akan lebih mampu mengatasi situasi yang menekan saat pertandingan berlangsung dan menjadikan sebagai tantangan yang positif yang dapat mengembangkan dirinya.

\section{Metode}

Penelitian ini menggunakan pendekatan kualitatif dan secara spesifik diarahkan pada penggunaan studi kasus karena dalam penelitian ini terdapat fenomena unik dan berfokus pada kasus yang mendalam yaitu partisipan dengan keterbatasan secara fisik, mental atau sensorial menjadi seorang atlet yang memiliki prestasi ditingkat internasional. Fenomena tersebut menjadi alasan peneliti untuk menggunakan studi kasus.

Populasi dalam penelitian ini adalah atlet paralympic di Surabaya. Sampel dalam penelitian ini ditentukan dengan kriteria partisipan penelitian. Sampel penelitian ini yaitu 1 atlet paralympic yang sesuai dengan kriteria yang ditetapkan. Kriteria dalam menentukan partisipan penelitian yaitu: atlet yang mengalami cacat fisik, mental atau sensorial; atlet cabang olahraga atletik nomor perlombaan lari cepat; pernah menjadi juara tingkat internasional dalam perlombaan paralympic.

Teknik pengumpulan data adalah wawancara, observasi dan data dokumentasi. Jenis wawancara yang digunakan yaitu wawancara semi terstruktur dan terbuka. Jenis observasi yang dilakukan adalah observasi partisipasi dimana peneliti turut mengambil bagian dalam kegiatan partisipan penelitian sedangkan dokumentasi dilakukan dengan review dokumen eksternal yang berupa data-data tentang sertifikat dan piagampiagam penghargaan partisipan penelitian.

Teknik analisis data yang digunakan yaitu Thematic Analysis (TA). Thematic analysis ini digunakan untuk mengatur dan menjelaskan rangkaian data dalam suatu rincian dalam bentuk tema sehingga memudahkan peneliti dalam menganalisis data berdasarkan tema yang terkait dengan fokus penelitian. Metode ini memungkinkan peneliti untuk terlibat dengan teori untuk mendapatkan analisis data yang lebih mendalam. 
Uji keabsahan data yang digunakan dalam penelitian ini yaitu uji kredibilitas dengan triangulasi. Triangulasi yang digunakan dalam keabsahan data adalah triangulasi sumber data yang melibatkan orang-orang terdekat partisipan penelitian atau yang biasa disebut significant other. Data informan ini akan menjadi penguat hasil wawancara dengan partisipan.

\section{Hasil}

Penelitian mengenai gambaran kecenderungan kepribadian hardiness pada atlet paralympic cabang olahraga atletik nomor perlombaan lari cepat berhasil mengungkap 5 tema yaitu pemahaman tujuan hidup, melibatkan diri dalam aktivitas yang dijalani, optimis, pengendalian masalah, dan berani mengambil tantangan. Subtema-subtema dalam tema ditentukan berdasarkan kodekode pada masing-masing data yang memiliki kesamaan pengertian. Subtema ini ditentukan berdasarkan pengertian dari masing-masing tema.

\section{Pemahaman tujuan hidup}

Tema ini terdiri dari 3 subtema, yaitu keinginan untuk maju, harapan masa depan dan pengambilan keputusan.

\section{Keinginan untuk Maju}

Partisipan melakukan beberapa cara yang menunjukkan bahwa terdapat keinginan untuk maju. Hal pertama yang dilakukan partisipan yaitu keputusan partisipan untuk bergabung dengan National Paralympic Committee.

"[...] NPC itu kita sama-sama berkebutuhan khusus nah disitu kan bisa bersaing bisa berkembang (AA050215, JR.7)"

Partisipan juga menunjukkan keinginan untuk maju yaitu pada saat ingin memperbaiki catatan waktu yang sebelumnya pernah dicetak olehnya.

“[...] cuma ingin berusaha memperbaiki catatan waktu yang sudah bapak cetak sebelumnya [...] (AA050215, JR.27)"

\section{Harapan Masa Depan}

Partisipan memiliki harapan untuk menjadi yang terbaik, baik ditingkat nasional maupun internasional. Harapan menjadi yang terbaik itu mampu membuatnya untuk bisa bertanding dan tetap berlatih dengan kemampuan semaksimal mungkin dan semangat yang ada.

“[...] kalah atau menang yang jelas bapak harus bertanding semaksimal mungkin dengan harapan menjadi yang terbaik. (AA050215, JR.20)"

Partisipan juga memiliki harapan untuk bisa menjadi contoh bagi atlet lain disetiap kemenangan ataupun kekalahan sehingga mampu memberikan motivasi bagi atletatlet yang lain.

"Iya masih tetap semangat, bapak kan
ingin memberikan motivasi kepada
teman-teman yang Junior ini $[\ldots]$
(AA050215, JR.31)"

\section{Pengambilan Keputusan}

Partisipan memutuskan untuk menjadi atlet karena ingin menyalurkan hobinya sejak kecil dan mengisi waktu luang untuk tujuan kedepannya partisipan ingin memberikan yang terbaik untuk Jawa Timur.

"Nggak, ingin sehat dan ingin menyalurkan hobi yang mulai kecil sudah bapak gemari, untuk menyalurkan hobi dan menyalurkan waktu yang kosong, untuk kedepannya ingin memberikan yang terbaik untuk Jawa Timur. (AA130215, JR.7)" 


\section{Melibatkan diri dalam aktivitas yang dijalani}

Tema ini terdiri dari 2 subtema, yaitu tanggung jawab yang dijalani dan menjalani rutinitas.

\section{Tanggung Jawab yang Dijalani}

Partisipan mengatakan bahwa dirinya mendapat kepercayaan dari temantemannya untuk bisa memimpin National Paralympic Committee cabang Surabaya. Partisipan menganggap bahwa terpilihnya menjadi ketua adalah suatu kepercayaan dari teman-temannya yang harus dijalani olehnya.

“[...] setelah ketemu NPC ya harus dijalani soale kan itu kan amanah dari organisasi dari teman-teman memilih bapak untuk memimpin NPC kedepan supaya ada perubahan yang lebih baik [...] (AA080315, JR.3).

Partisipan memiliki beberapa tanggung jawab sebagai ketua National Paralympic Committee, diantaranya yaitu memberikan motivasi pada atlet atau pelatih atau memberikan beberapa masukan yang didapatkannya dari berbagai pengalamannya selama berkarir menjadi atlet yang tentunya bisa menimbulkan dampak positif dan bertanggung jawab untuk mendatangi setiap rapat yang diselenggarakan.

\section{“[...] memberikan support, motivasi pada teman-teman, pelatih, memberikan pengalaman-pengalaman yang mereka tidak punya, bapak berikan tambahan- tambahan masukan yang bapak dapat dari pengalaman yang telah dijalani $[\ldots]$ (AA050215, JR.38)"}

\section{Menjalani Rutinitas}

Rutinitas sebagai ketua dan atlet bukanlah sesuatu yang mudah untuk dijalani, ditambah lagi partisipan membuka usaha pakaian olahraga sehingga membuatnya mengatur waktu dengan baik.

“[...] seumpamanya bapak nggak kerja katakanlah hari senin ya senin bisa berlatih pagi sore, kalau sudah saatnya mencari nafkah ya berlatihnya sore hari saja jam setengah empat sampai jam 5 [...] (AA050215, JR.39)"

Rutinitas yang selalu padat dan hanya sedikit waktu untuk bisa beristirahat mungkin akan menimbulkan kejenuhan pada individu yang menjalani, hal tersebut juga terjadi pada partisipan namun tidak dalam kapasitas yang besar.

"Iya kalau ditanya mengalami kejenuhan ya mungkin mungkin ada tapi nggak terlalu banyak [...] (AA080315, JR.3)"

\section{Bersikap optimis}

Tema ini terdiri dari 2 subtema, yaitu tidak mudah menyerah dan keyakinan dalam diri.

\section{Tidak mudah menyerah}

Sikap tidak mudah menyerah ditunjukkan ole partisipan dalam menanggapi setiap kegagalan dalam pertandingan. Partisipan tetap semangat berlatih untuk kegagalannya dalam mencapai target yang diinginkan. Setiap kegagalan yang pernah dialami oleh partisipan membuatnya lebih melakukan persiapan yang matang dan tetap berusaha keras untuk bisa meraih prestasi dan tidak mengalami putus asa disetiap usahanya meraih prestasi.

"Nah itu nggak lolos di Atlanta itu, bapak terus berlatih tahun ' 96 pada saat itu, setelah gagal bapak pulang lalu berlatih terus, berlatih, berlatih, berlatih [...] (AA050215, JR.29)"

\section{Keyakinan dalam diri}


Partisipan memiliki keyakinan diri, hal ini ditunjukkan dengan tekat yang kuat selama menjalani persiapan sebelum bertanding maupun saat bertanding, Partisipan tidak begitu memperhatikan bagaimana jika dirinya mengalami kegagalan, partisipan hanya bertekat untuk bisa bertanding semaksimal mungkin.

“[...] jadi bertekadnya cuma itu tadi keyakinan dan rasa optimis yang menggebu-gebu, urusan kalah wes nggak роро (AA080315, JR.8)"

Partisipan juga mengatakan bahwa dirinya tidak memiliki rasa takut gagal dalam setiap pertandingan, bahkan saat melawan lawan-lawan yang lebih muda darinya.

"Kalau perasaan takut gagal itu nggak [...] (AA130215, JR.12)"

\section{Pengendalian masalah}

Tema ini terdiri dari 3 subtema, yaitu mengatasi kecemasan dalam pertandingan, strategi meminimalisir kesalahan, dan mengatasi kekalahan.

\section{Mengatasi Kecemasan dalam Pertandingan}

Partisipan mampu mengatasi kecemasan dalam bertanding dengan cukup baik, partisipan mengungkapkan bahwa tidak ada perasaan tertekan selama menjalani pertandingan karena memang jam terbangnya dalam dunia atlet sudah tinggi.

"Perasaan tertekan tidak ada, soalnya kan bapak jam terbangnya sudah tinggi [...] (AA050215, JR.20)"

Partisipan mengatakan bahwa dirinya pernah mengalami rasa tegang, namun mampu mengatasi rasa tegang selama pertandingan dengan rasa percaya diri yang tinggi.
"Ya ada sih perasaan tegang sedikit cuma bapak bisa membuang perasaan itu dengan rasa percaya diri $[\ldots]$ (AA130215, JR.21)"

\section{Strategi Meminimalisir Kesalahan}

Partisipan mengutarakan salah satu cara dalam meminimalisir kesalahan yaitu dengan berusaha untuk mentaati peraturan yang ada dalam pertandingan. Usaha yang dilakukan dalam mentaati peraturan yaitu partisipan berusaha untuk tidak melakukan diskualifikasi saat start awal.

“[...] meminimalisir itu ya mungkin untuk di event pertandingannya itu bapak berusaha untuk tetap mentaati peraturan [...] (AA080315, JR.7)"

\section{Mengatasi kekalahan}

Kekalahan yang pernah dialami oleh partisipan tidak membuatnya merasakan kekecewaan yang mendalam, partisipan segera berusaha untuk memperbaiki dengan melakukan persiapan untuk pertandingan selanjutnya.

"Nah, nggak ada perasaan kecewa yang berlarut-larut, setelah pulang dari daerah, bapak melakukan persiapan untuk eventevent yang terdekat [...] (AA050215, JR.22)"

Partisipan juga mampu menyikapi dengan lapang dada dan besar hati untuk setiap kekalahan yang diterimanya dan memandang bahwa kekalahan itu sebagai pengalaman yang berharga yang mampu meningkatkan kemampuannya melalui belajar dari kekuatan lawan yang lebih baik darinya.

“[...] jadi kita tetap menerima kekalahan itu dengan besar hati karena masa emas kita sudah lewat disitu. (AA130215, JR.33)”

Kekalahan yang dihadapi oleh partisipan membuatnya berusaha untuk 
mengkoreksi dirinya dengan melihat apa yang menjadi kekurangannya.

“[...] setelah pulang dari seleksi nasional bapak istilahnya mengkoreksi diri, apa kekurangan bapak. (AA130215, JR.27)"

\section{Berani mengambil tantangan}

Partisipan mengatakan bahwa dirinya pernah menjalani perubahan dalam pertandingan yang mengharuskan dirinya untuk mencoba nomor pelombaan lain. Partisipan menganggap bahwa percobaan di nomor perlombaan lain adalah suatu tantangan tersendiri baginya, partisipan mampu melihat peluang untuk bisa mendapatkan medali melalui nomor perlombaan lain tersebut.

“istilahnya sebuah tantangan, kalau bapak nggak bermain dinomor alternatif bapak cuma pulang bawa 1 medali, 400 meter emas itu tapi bapak ingin mencoba yang dadakan dengan semangat $[\ldots]$ (AA130215, JR.26)"

Partisipan juga mampu menerima tantangan ketika menjadi wakil Indonesia dalam pertandingan Paralympic tingkat internasional dan hal itu membuatnya merasa bangga karena telah diberi kesempatan wakil Indonesia.

“[...] ya bapak senang saja, bapak bisa mewakili Jawa Timur untuk pelatnas dan bisa berangkat ke Olimpiade untuk Indonesia (AA130215, JR.29)"

\section{Pembahasan}

Penelitian ini berfokus pada gambaran kecenderungan kepribadian hardiness pada atlet paralympic yang berada pada cabang olahraga atletik dengan nomor perlombaan lari cepat yang telah meraih prestasi ditingkat internasional. Prestasi yang diraih hingga tingkat internasional tentu bukan suatu hal yang mudah untuk didapatkan bagi atlet paralympic yang memiliki keterbatasan secara fisik, mental maupun sensorial. Hasil penelitian mengenai kecenderungan kepribadian hardiness pada atlet paralympic ini memiliki pola yang sama dengan teori mengenai aspek-aspek kepribadian hardiness menurut pernyataan Kobasa (dalam Kreitner \& Kinicki, 2005) yaitu dengan adanya commitment, control dan challenge.

Individu yang memiliki kecenderungan kepribadian hardiness memiliki komitmen yang tinggi. Penelitian ini menghasilkan 2 indikasi jika atlet memiliki komitmen dalam mencapai prestasinya yaitu adanya pemahaman tujuan hidup dan melibatkan diri dalam aktivitas yang dijalani. Menurut Kobasa (dalam Kreitner \& Kinicki, 2005) individu dengan kecenderungan kepribadian hardiness akan memiliki pemahaman tujuan hidup. Atlet menetapkan tujuannya dalam berkarir di dunia olahraga. Menurut Locke (2002) untuk mencapai tujuan yang efektif individu harus berkomitmen kepada tujuannya. Hal ini dibutuhkan ketika individu tersebut dihadapkan pada tujuan yang sulit dicapai sehingga membutuhkan pemikiran dan usaha yang keras. Tujuan yang telah ditetapkan menuntut atlet untuk mampu mencapainya dengan berbagai cara dan berusaha dengan semaksimal mungkin.

Penelitian ini mengungkap adanya tujuan yaitu keinginan untuk maju dan harapan masa depan, kedua tujuan tersebut membuat individu untuk mengambil keputusan sehingga tujuan tersebut dapat tercapai. Menurut Snyder, dkk (2002), tujuan yang samar biasanya jarang muncul pada individu yang memiliki pemikiran harapan yang tinggi, sedangkan penetapan tujuan yang spesifik biasanya ditemukan pada orang dengan pemikiran harapan yang tinggi dan memudahkannya untuk membayangkan pathways yang dimiliki. Menurut Jomhari (dalam Dogaheh dkk, 2014) kepribadian hardiness merupakan kemampuan untuk memahami kondisi eksternal secara akurat dan untuk membuat keputusan yang diinginkan tentang diri 
sendiri. Setiap keinginan atau tujuan yang diharapkan membuat individu mengambil keputusan cara terbaik dalam mencapai tujuan tersebut.

Indikasi kedua yang menunjukkan adanya komitmen dalam penelitian ini yaitu melibatkan diri dalam aktivitas yang dijalani. Menurut Kobasa (dalam Kreitner \& Kinicki, 2005) komitmen mencerminkan sejauh mana individu terlibat dalam aktivitas yang sedang dilakukan. Keterlibatan tersebut menunjukkan adanya tanggung jawab, individu yang memiliki tanggung jawab akan menjalani tanpa adanya keterpaksaan. Menurut Locke (2002), membenci tanggung jawab untuk mencari nafkah sama saja dengan membenci realitas. Individu yang membenci tangggung jawab tidak akan bisa ditekan menemukan kebahagiaan dalam pekerjaan atau tempat lain. Menurut Locke (2002) sukses dalam pekerjaan, seperti dalam kehidupan membutuhkan usaha keras termasuk kemauan yang konsisten yang membuat individu tersebut tetap berpikir. Atlet yang menginginkan untuk bisa berhasil dalam pekerjaan yang dilakukan akan selalu terlibat secara aktif dan berusaha untuk memenuhi tuntutan aktivitas tersebut.

Individu yang memiliki kecenderungan kepribadian hardiness juga memiliki kontrol yang tinggi dalam menanggapi suatu kejadian. Menurut Kobasa (dalam Kreitner dan Kinicki, 2005) kontrol melibatkan keyakinan bahwa individu mampu untuk mempengaruhi kejadian-kejadian dalam hidupnya. Individu yang memiliki ciri seperti ini lebih cenderung meramalkan peristiwa yang menimbulkan stres sehingga dapat mengurangi keadaan yang tertekan. Permasalahan seringkali menjadi kondisi yang mampu menimbulkan stres dalam diri individu. Masalah yang dialami oleh atlet seringkali terjadi seputar pertandingan sehingga tentu akan menghambat jalannya pertandingan dan membuat performa atlet menjadi menurun dibandingkan dengan saat latihan, hal itu terjadi apabila atlet tersebut tidak mampu menyesuaikan diri ataupun menyelesaikan permasalahan saat itu juga sehingga dapat dipastikan hanya kegagalan yang akan didapatkan oleh atlet tersebut.

Salah satu permasalahan yang sering terjadi yaitu kecemasan saat pertandingan berlangsung. Menurut E.E Lavit (dalam Herman, 2011) mengatakan bahwa rasa cemas adalah perasaan diri sendiri terhadap ketakutan dan meningkatkan kegairahan secara fisiologik. Perasaan cemas yang dialami atlet akan berbeda, hal ini disebabkan karena tingkat pengalaman yang berbeda, biasanya pengalaman yang banyak tidak akan merasakan kecemasan. Menurut Issacson (dalam Dogaheh dkk, 2014) individu dengan kepribadian hardiness berkaitan dengan penyesuaian dan kesepakatan positif dalam menghadapi masalah. Individu yang mampu menyesuaikan diri dengan baik akan tetap bertahan dalam menghadapi masalah. Menurut Kobasa (dalam Sari, 2013) individu dengan kontrol yang tinggi memiliki keterampilan untuk mengatasi masalah dengan respon-respon yang tepat. Individu yang mengalami tekanan atau rasa tegang akan belajar bagaimana cara untuk bisa menyesuaikan diri dalam mengatasi permasalahan tersebut. Penyesuaian diri yang baik merupakan tindakan yang terarah pada penguasaan ketegangan.

Permasalahan yang juga terjadi dalam dunia atlet yang sering mempengaruhi segi kehidupan yaitu kegagalan dalam pertandingan. Kegagalan yang diterima oleh atlet akan menjadi beban dan menimbulkan perasaan kecewa dan bahkan terasa sulit untuk mendapatkan semangat berlatih atau semangat bertanding dan mengalami rasa ketakutan akan kegagalan kembali di pertandingan selanjutnya. Menurut Conroy (2001) definisi mengenai ketakutan akan kegagalan mencakup adanya antisipasi terhadap konsekuensi negatif yang didapatkan dari kegagalan dan 
tidak adanya harapan untuk bisa sukses. Atlet yang mampu mengatasi masalah kegagalan tersebut tidak akan memiliki kecemasan dan ketakutan kemungkinan menghadapi kegagalan dan konsekuensi negatif kegagalan tersebut yang akan berpengaruh pada pertandingan selanjutnya. Hal yang akan dilakukan adalah tidak berlarut dalam kekecewaan, berusaha untuk bangkit kembali, dengan tetap menerima kekalahan dan melakukan introspeksi diri sehingga mengetahui kekurangan selama pertandingan sebelumnya.

Permasalahan yang juga terjadi dalam dunia atlet yang sering mempengaruhi segi kehidupan selain yaitu kegagalan dalam pertandingan. Atlet yang mampu mengatasi kegagalan tersebut, tidak memiliki ketakutan akan kegagalan kembali, atlet tersebut cenderung mampu menerima kekalahan dan tidak berlarut dalam kekecewaan kegagalan tersebut. Seorang atlet tidak hanya menerima kekalahan atau menunjukkan emosi yang positif dalam setiap kekalahan, namun juga berusaha untuk mengevaluasi performanya pada pertandingan sebelumnya. Evaluasi diri digunakan untuk mengetahui kelemahan dan kelebihan pada atlet tersebut. Bekal dari pengetahuan tentang dirinya, atlet dapat menentukan target latihan maupun target pertandingan dan cara mengukurnya.

Optimis juga menunjukkan adanya kontrol diri yang kuat selain adanya pengendalian dalam menghadapi permasalahan. Kobasa (dalam Sari, 2013) individu yang memiliki kontrol akan menerima dan percaya bahwa mereka dapat mengontrol dan mempengaruhi kejadian dengan pengalamannya ketika berhadapan dengan hal-hal yang tidak terduga. Menurut Robazza dan Bortoli (dalam Besharat, 2011) keyakinan diri menjadi salah satu aspek yang penting untuk kinerja dalam olahraga dan meningkatkan kemampuan untuk manajemen emosi dan memberikan kemungkinan bagi atlet untuk mampu mengendalikan emosi negatif lebih efektif. Menurut Craft, dkk (dalam Besharat, 2011) keyakinan diri sebelum dan selama pertandingan menentukan tingkat yang lebih rendah dari kecemasan persaingan dan sering berkorelasi dengan kinerja yang lebih baik. Keyakinan dalam diri ini membuat kecemasan dalam persaingan lebih rendah sehingga membuat seorang atlet bisa menunjukkan kinerja yang baik saat berada di lapangan.

Aspek yang ketiga untuk menunjukkan kecenderungan kepribadian hardiness yaitu tantangan. Menurut Kobasa (dalam sari, 2013) tantangan adalah kecenderungan memandang perubahan dalam hidupnya sebagai sesuatu yang wajar dan memandang perubahan tersebut sebagai stimulus yang berguna bagi perkembangan diri. Atlet yang memiliki kepribadian hardiness memandang tantangan bukan suatu ancaman bagi dirinya dan mampu mengambil sisi positif pada setiap tantangan yang dijalani sebagai suatu yang dapat mengembangkan dirinya.

Kecenderungan kepribadian hardiness mengarah pada kemampuan dalam untuk menghadapi situasi yang menekan dengan pengalaman yang telah ada dan tidak memandang situasi yang menekan sebagai ancaman bagi dirinya. Atlet paralympic yang memiliki keterbatasan baik secara fisik, mental atau sensoral diharuskan untuk mampu mengatasi permasalahan terutama pada menurunnya rasa kepercayaan diri yang disebabkan keterbatasan yang dimiliki yang dapat menimbulkan stres tersendiri bagi atlet paralympic selama pertandingan sehingga atlet paralympic tidak mampu untuk menunjukkan kinerja terbaiknya.

\section{Simpulan}

Berdasarkan hasil dan pembahasan yang diungkapkan dalam penelitian ini maka dapat disimpulkan atlet paralympic yang memiliki kecenderungan kepribadian 
hardiness mengarah pada kemampuan dalam mengatasi situasi yang menekan sehingga mampu untuk meraih tujuan yang diharapkan dalam dunia olahraganya. Hasil penelitian mengenai kecenderungan kepribadian hardiness pada atlet paralympic ini memiliki pola yang sama dengan teori mengenai aspek-aspek kepribadian hardiness menurut pernyataan Kobasa (dalam Kreitner \& Kinicki, 2005) yaitu adanya commitment, control dan challenge. Penelitian ini berhasil mengungkap adanya commitment, control dan challenge untuk menunjukkan kecenderungan kepribadian hardiness pada atlet paralympic.

Commitment diperlihatkan dengan adanya pemahaman tujuan hidup dan melibatkan diri dalam aktivitas yang dijalani. Control ditunjukkan oleh atlet yang memiliki optimis dan mampu untuk mengendalikan setiap masalah baik dalam pertandingan maupun setelah pertandingan berlangsung. Challenge dapat dilihat dengan memandang bahwa perubahan sebagai tantangan, dalam hal ini individu akan berani mengambil tantangan atau dalam artian tidak membuang setiap kesempatan yang ada. Atlet paralympic yang memiliki keterbatasan secara fisik, mental maupun sensorial tidak menjadi hambatan untuk mampu meraih prestasi. Atlet paralympic yang mengarah pada kecenderungan kepribadian hardiness akan memiliki kemampuan dalam menghadapi situasi yang menekan selama pertandingan berlangsung dan mampu untuk bangkit kembali setelah mengalami kegagalan

\section{Daftar Pustaka}

Adisasmito, L.S. (2007). Mental Juara: Modal Atlet Berprestasi. Jakarta: PT. Rajawali Grafindo Indonesia.

Besharat, Mohammad Ali. (2011). Moderating Effects of Self-Confidence and Sport Self-Efficacy on the Relationship between Competitive Anxiety and Sport Performance. sehingga dapat menunjukkan performa dan mampu meraih prestasi yang menjadi tujuan selama menjadi atlet.

\section{Saran}

Berdasarkan uraian penjelasan dan kesimpulan diatas, maka terdapat beberapa saran yang mungkin bisa menjadi bahan pertimbangan bagi pihak-pihak terkait. Kepribadian hardiness yang memiliki peran penting bagi atlet paralympic yang membutuhkan kepercayaan diri yang tinggi untuk dapat mengatasi tekanan dan mencapai prestasi, maka saran yang diberikan adalah agar mereka menjaga konsistensi pemahaman tujuan dan selalu terlibat dalam aktivitas yang dijalani selama menjadi atlet sehingga adanya upaya untuk dapat mencapai tujuan yang diharapkan. Selain itu, mereka perlu meningkatkan optimisme dan kemampuan mengendalikan masalah dalam pencapaian prestasi.

Bagi pelatih dan pihak terkait dalam pengembangan atlet paralympic. Pihak luar juga memiliki peran yang mendukung atlet untuk mampu mengembangkan karakteristik kepribadian yang mengarah pada kepribadian hardiness, sehingga melalui pemahaman yang mendalam mengenai kepribadian hardiness maka saran yang diberikan: selain itu mereka juga perlu memotivasi atlet paralympic sehingga atlet tersebut mampu mengarah pada kepribadian hardiness. Terakhir, dapat dicanangkan pengadaan berbagai program pelatihan yang dapat meningkatkan ketahanan psikologis pada atlet paralympic.

Journal of Scientific Research 2 (7), 760-765. (online). http://www.scirp.org. Diakses 23 maret 2015.

Conroy, D. E., Poczwardowski, A., \& Henchen, K. P. (2001). Evaluative Criteria and Consequences Associated With Failure and Success for Elite 
Athletes and Perfoming Artist. Journal of Applied Sport Psychology 13, 300322. (online). http://psicdesp.no.sapo.pt. Diakses 23 Maret 2015.

Dogaheh, E.R., Khaledian, M., \& Arya, A.R.M. (2014). The Relationship of Psychological Hardiness with Emotional Intelligence and Workaholism. Iranian Journal of Clinical Psychology (IJCP) 2 (1). (online). http://jpcp.uswr.ac.ir. Diakses 23 Maret 2015.

Griwijoyo, S. (2005). Manusia dan Olahraga. Bandung: Institut Teknologi Bandung.

Herman. (2011). Psikologi Olahraga. Jurnal ILARA 11 (2), 1-7. (online). http://digilib.unm.ac.id. Diakses 23 Maret 2015.

Johnson, B.F., Richter, K., Musheet, C.A., and Peacock, G. (2004). Sport for Athletes with Physical Disabilities: Injuries and Medical Issues. (online). http://www.blazesports.org. Diakses 22 Oktober 2015.

Kreitner, R. dan Kinicki, A. (2005). Perilaku Organisasi. (Alih Bahasa: Erly Suandy). Jakarta: Salemba Empat.

Locke, E. A. (2002). Setting Goals for Life and Happiness. In Snyder \& Lopez,
Handbook of Positive Psychology. New York: Oxford University Press.

Mehrparvar \& Mazaheri. (2012). A Comparative Study of Psychological Hardiness in Athlete and Non-Athlete Students. European Journal of Experimental Biology 2 (5), 15141516. (online) http://pelagiaresearchlibrary.com.

Diakses 22 Oktober 2014.

Nurhasan, Priambodo, A., Roepajadi, J., Indriarsa, N., Ivano, A.R., Christiana, Y.H.S., Tjateri, G.A., Juniarto, P., Djawa, B., \& Wibowo, S. (2005). Petunjuk Praktis Pendidikan Jasmani. Surabaya: Unesa University Press.

Sari, R.I. (2013). Hardiness dengan Problem Focus Coping pada Wanita Karir. Jurnal Online Psikologi 1 (2). (online). http://ejournal.umm.ac.id. Diakses 13 Januari 2015.

Snyder, C.R., Rand, K. L., \& Sigmon, D. R. (2002). Hope Theory: a member of the positive psychology family. In Snyder \& Lopez, Handbook of Positive Psychology. New York: Oxford University Press.

Wadey, R.G. (2009). An Examination of Hardiness Throughout The Sport Injury Process. (online). http://core.ac.uk. Diakses 21 Oktober 2014. 